\title{
Four Paths to Success in the Hospitality Industry
}

\author{
Michael C. Sturman, Jack B. Corgel, and Rohit Verma
}

The book you are about to read distills and shares the expertise of the faculty of the world's preeminent school focusing solely on hospitality industry education. Founded in 1922 at the specific request of the hotel industry, the Cornell University School of Hotel Administration is the oldest school of its kind and the only Hotel School within an Ivy League university. Our mission is to promote hospitality leadership, which we achieve through a combination of teaching, research, and industry collaboration. The 70 faculty members of the school seek to expand the state of knowledge in the industry-whether by creating new knowledge through research, teaching those who are eager to learn, or disseminating knowledge through consulting, writing, and presentations-and help develop the future leaders of the hospitality industry.

This book is another means through which we achieve our mission, and our intent is to give you a comprehensive overview of the hospitality industry. Although we've been sharing research information with our industry from the very beginning, we have never attempted to compile a book such as this one, where we go into detail on the breadth of topics studied at our school. The chapters include the contributions of 28 of our faculty, who have a combination of over 450 years of teaching, 400 years of research, 250 years of hospitality industry experience, and 350 years of consulting with the industry. Selected alumni and friends of the school also made valuable contributions to the book. As we share with you much of what we know about the industry, we hope to provide you with both a broad introduction to topics pertinent to the industry and insights that reflect in-depth state-of-the-art thinking. We combine theory and application, experience and learning, and lessons from the past with visions of the future.

\section{Organization of the Book}

We begin the book with the view that business is service. While this book provides insights from a variety of disciplines on a diversity of topics, it is valuable to reflect first on the business we are in. Chapter 2 captures the essence of hospitality and service and the views of service-providers who truly 
"get it," from famous leaders in the field to dedicated line-level employees. This then sets the stage for the rest of the book.

When we began organizing this book, we sought to organize it around a clear theme. The unwritten subheading for the book became How to Be Successful in the Hospitality Industry. The resulting sections of the book align with the following four "paths to success," which reflect the various disciplines studied in the Cornell University School of Hotel Administration:

- Section 1: Success in Your Hospitality Career

- Section 2: Success through Operations and Service Excellence

- Section 3: Success as a Real Estate and Business Owner

- Section 4: Success through Managerial Excellence

Each section describes a different way in which you can be successful in the hospitality industry. The first section considers how you can be a success from the perspective of managing your career. If you are new to the industry, how do you break in? Once in the industry, how do you develop yourself to become a leader in the industry? Jobs in the hospitality industry require you to have certain knowledge, skills, and abilities so you can move up the organizational ladder. The industry also requires the right personal characteristics so that you can love what the job requires and can make a career in the industry a good fit. This section of the book builds on what we have learned about educational and personal development at Cornell's School of Hotel Administration that has worked to create successful careers in the hospitality industry. Chapters in this section include contributions by our faculty in communications, human resources, management, and organizational behavior.

The second section moves from the individual to the business. Any successful hospitality operation-be it a hotel or restaurant, chain or independent, low-cost provider or luxury establishment-requires an effectively performing individual operation. You have to attract the right customers, have the service product, set the right price for your product, and provide the right level of service-all the while managing your employees the right way to achieve your goals. This requires a combination of knowledge from a variety of disciplines, and thus this section includes contributions from our faculty in human resources, management, marketing, operations, and strategy.

The book's third section considers the path to success you may follow as an owner. Ownership of property serves as an important part of the foundation for entire economies, social systems, and individual industries, not the least of which is the hospitality industry. The wealth of hospitality owners increases in accordance with their ability to build and retain their operation's cash flows. In this industry, 
you can achieve success by owning hotels, restaurants, and other types of hospitality businesses, by owning the real estate underlying these businesses, and by owning both. This section of the book is intended to help you understand the actions available to owners for wealth creation that have been developed and studied at the Cornell University School of Hotel Administration. In many important components of the hospitality industry, control of the business operations has become increasingly separated from ownership of the real estate. The chapters in this section therefore emphasize the profitable actions of hospitality real estate owners who hold the rights to the residual cash flows from their properties. Contributions to this section come from our faculty in finance and real estate, along with prominent school alumni.

The final section of the book takes the perspective of the decision maker in the corporate office - or the person who is responsible for leading a business team at any level. The requirements for managerial excellence when managing a chain of properties or restaurants differ in magnitude from those when managing a single property (although the industry's different levels have many principles in common). At the corporate office, you need to choose the right strategy, manage your brand, coordinate information, control costs, and implement the right systems to achieve success at multiple locations simultaneously. Single-unit operators or those with several units also share many of these strategic responsibilities. Based on our studies of the hospitality industry, this section highlights some of the major areas that require attention to successfully manage a set of hotel properties or restaurants, and provides guidance as to what research and experience has shown can enhance your likelihood of operating a successful multiunit company. Contributions come from a diverse faculty, representing accounting, human resources, law, management, marketing, operations, and organizational behavior.

\section{Paths to Your Success}

The paths to success described in this book provide you with what we believe is an insightful introduction to content provided at Cornell University's School of Hotel Administration. Our current curriculum exposes our students to each of these paths, providing them with the opportunity to pursue them as they see best. Alumni of the school provide innumerable examples of those who have found success down each of these routes-some have joined the corporate world, others have set up consultancies to assist industry operators, and many have become entrepreneurs in their own right. Importantly, our graduates return to the school and share their learning with the faculty and with current students. The lesson here is that you are not required to pick only one of the four paths we examine in this book. Indeed, the best and the brightest, and the most successful in the industry, have 
pursued all four at some point during their careers. Whatever career you choose, you need to manage that career, but that career may bring you through managing a single property, owning a property, and then even owning multiple properties and running a chain.

As co-editors of this book, we have combined and organized a wealth of information, from an institution representing one of the best sources of hospitality industry knowledge that exists. While each chapter is based on extensive research and industry experience, we have sought to communicate this information in a clear, straightforward, nonacademic way. We believe that you will find this material interesting, but more importantly, we hope you find it to be useful. That is, we expect that what you learn from this book will change the way you manage your career and your operation. It is by fostering change that the Cornell University School of Hotel Administration succeeds in furthering the state of the art in hospitality, and ultimately in helping forge hospitality leaders. By disseminating knowledge, our goal is to provide insights that help you do something differently than you would have without that knowledge. That's why this book doesn't so much present specific data on the industry (although that's in here), as it provides actionable information. At Cornell University's School of Hotel Administration, we aim to bridge the gap between science and practice. By reducing the divide that often exists between the two, we hope to assist current and future leaders of the hospitality industry in knowing how to conduct their business better-for everyone's benefit. 